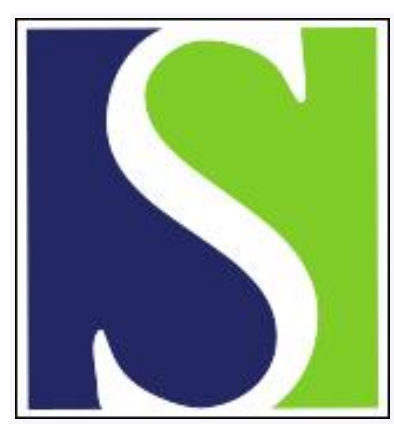

Scand J Work Environ Health 1998;24(2):153-156

https://doi.org/10.5271/sjweh.293

Issue date: Apr 1998

Predictors of blood lead concentrations in the lead-free gasoline era

by Nielsen JB, Grandjean P, Jørgensen PJ

Key terms: age; alcohol consumption; gender; health risk; vitamin intake

This article in PubMed: www.ncbi.nlm.nih.gov/pubmed/9630064

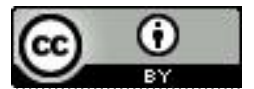




\title{
Predictors of blood lead concentrations in the lead-free gasoline era
}

\author{
by Jesper B Nielsen, MSc, ${ }^{1}$ Philippe Grandjean, MD, ${ }^{1}$ Poul J Jørgensen, MSc ${ }^{2}$
}

\begin{abstract}
Nielsen JB, Grandjean P, Jørgensen PJ. Predictors of blood lead concentrations in the lead-free gasoline era. Scand $J$ Work Environ Health 1998;24(2):153-6.

Objectives Blood lead concentrations in a Danish reference population were related to information from an extensive questionnaire on work, environment, and life-style.

Methods Data were gathered for 209 persons by means of a questionnaire and blood lead analyses.

Results The mean concentration of lead in blood was $0.167 \mu \mathrm{mol} / \mathrm{l}$ (ie, significantly lower than in previous studies). This finding is in accordance with the fact that less than $10 \%$ of the gasoline used in Denmark contains lead additives (up to $0.15 \mathrm{~g} / \mathrm{l}$ ). An important finding was that the well-documented predictors for lead in blood at higher concentration levels, such as age, gender, menopausal status, and intake of alcohol, are still valid in a low-level exposure situation. In addition, a strong and negative correlation was found between blood lead concentrations and dietary supplementation with vitamins and minerals.

Conclusions The present data indicate that lead exposure may still constitute a health risk in a small proportion of adult men and postmenopausal women.
\end{abstract}

Key terms age, alcohol consumption, gender, health risk, vitamin intake.

Evidence of neurotoxicity has increased the awareness concerning low-level, nonoccupational lead exposure. The lead concentration in whole-blood has been used as a proxy for the biologically active body burden of this metal (1). Blood lead (B-Pb) concentrations as low as $0.48 \mu \mathrm{mol} / 1$ have been associated with adverse effects on behavior and development in children (1). Furthermore, recent data suggest that $\mathrm{B}-\mathrm{Pb}$ concentrations of about $0.38 \mu \mathrm{mol} / \mathrm{l}$ may be associated with decreased cognitive function in postmenopausal women (2).

Thus, despite the well-documented reductions in $\mathrm{B}-\mathrm{Pb}$ levels in the general populations in many countries ( $3-5)$, lead remains a toxicologic issue, and the identification of variables affecting $\mathrm{B}-\mathrm{Pb}$ concentrations remain important.

The objective of this study was to describe $\mathrm{B}-\mathrm{Pb}$ concentrations in a reference population and relate the findings to information from an extensive questionnaire covering topics related to occupational exposure, traffic exposure, overall health, food habits, intake of alcohol, smoking and sociodemographic parameters. Furthermore, the results were related to a previous study on an identical population in Funen 5-6 years before $(6)$.

\section{Study population}

A reference population was established in Funen, Denmark, consisting of 219 persons ( 110 men and 109 women) ran- domly selected from the Danish central register of residents according to the following criteria: 20 men and 20 women in each age decade between 20 and 89 years, half residing within the city and the other half within rural communities. No exclusion criteria were used, except the ability to fill out the questionnaire. As in a previous study (6), the participants were included consecutively, after they signed an informed consent form, until their respective subgroups were filled. The overall response rate was $70 \%$, and among the respondents $44 \%$ accepted to participate. The participation rate was particularly low in the 2 oldest age decades (6\% and $19 \%$ ), and the anticipated number of subjects was not reached in these 2 age decades within the time limits of the study. Information regarding health, dietary habits (intake of meat, fruit, vegetables, coffee, tea, etc), use of dietary supplements (vitamins, minerals), alcohol consumption, smoking (including passive smoking), use of prescribed drugs, occupational exposures, hobbies, traffic, and housing situation were obtained by questionnaire and a subsequent interview. Approximately $60 \%$ of the sample group was currently employed. Other participants were students, retirees, or unemployed persons. Forty-three percent were current smokers, $23 \%$ were ex-smokers, and $32 \%$ had never smoked. According to these data, the sample group did not deviate from the general Danish population during the sampling period in $1994(7,8)$. The

1 Institute of Community Health, Odense University, Odense, Denmark.

2 Department of Clinical Chemistry, Odense University Hospital, Odense, Denmark.

Reprint requests to: Jesper B Nielsen, Institute of Community Health, Odense University, Winsløwparken 17, DK-5000 Odense C, Denmark. 
reference population had previously been used to establish reference intervals for malondialdehyde (an indicator for lipid peroxidation) and antioxidative enzymes $(9,10)$.

\section{Methods}

Lead analysis. The B-Pb concentrations were read in $\mathrm{du}-$ plicate against a blood-based standard curve with standard reference material SRM 955 (National Institute of Standards and Technology, Gaitherburg, Maryland, United States) as the primary standard. SeronormO Trace Element batches 901 and 902 (NycoMed, Oslo, Norway) were used as quality control materials. The total analytical imprecision $(\mathrm{N}=38)$ was estimated to be $3.0 \%$ and $2.0 \%$ at $\mathrm{B}-\mathrm{Pb}$ concentrations of 0.22 and $1.58 \mu \mathrm{mol} / 1$, respectively. In the earlier study (6), the same 2 control materials were 0.23 and $1.63 \mu \mathrm{mol} / \mathrm{l}$ (ie, almost identical to the values obtained in the present study). A comparison of the 2 sample groups must thus be justified. The assigned values were 0.3 and $1.6 \mu \mathrm{mol} / \mathrm{l}$ for the 2 materials. The detection limit was $0.05 \mu \mathrm{mol} / \mathrm{l}$.

Statistics. Statistical analyses were performed using SPSS 6.1 software (SPSS, Chicago, Illinois, United States). Goodness-of-fit to normal distribution was assessed by probit plot and K-S-test. The logarithmic transformation of the B-Pb concentrations approached a Gaussian distribution. Pearson's correlation coefficient was used to assess associations between $\mathrm{B}-\mathrm{Pb}$ concentrations and age. The differences in the mean values were analyzed by the independent sample's

Table 1. Mean values of blood lead in a reference population and the correlation with age.

\begin{tabular}{|c|c|c|c|c|c|}
\hline & \multirow[t]{2}{*}{ N } & \multicolumn{2}{|c|}{$\begin{array}{c}\text { Blood lead } \\
\text { concentration } \\
(\mu \mathrm{mol} / \mathrm{l})\end{array}$} & \multirow[t]{2}{*}{$\begin{array}{l}\text { Correlation } \\
\text { coefficient } \\
\text { (r) }\end{array}$} & \multirow[t]{2}{*}{ Significance } \\
\hline & & Mean & SD & & \\
\hline Total population & 219 & 0.167 & 0.101 & 0.263 & $<0.001$ \\
\hline Women & 109 & 0.143 & 0.099 & 0.372 & $<0.001$ \\
\hline Men & 110 & 0.191 & 0.097 & 0.150 & 0.119 \\
\hline
\end{tabular}

Table 2. Geometric means of the blood lead (B-Pb) concentration in the reference population. Comparison between men and women.

\begin{tabular}{|c|c|c|c|c|c|}
\hline \multirow[t]{2}{*}{ Age (years) } & \multicolumn{2}{|c|}{ Men } & \multicolumn{2}{|c|}{ Women } & \multirow{2}{*}{$\begin{array}{l}P \text { (t-test } \\
\text { 2-tailed) }\end{array}$} \\
\hline & $\begin{array}{c}\text { Geometric } \\
\text { mean B-Pb } \\
\text { concen- } \\
\text { tration } \\
(\mu \mathrm{mo} / / \mathrm{l})\end{array}$ & $N$ & $\begin{array}{c}\text { Geometric } \\
\text { mean B-Pb } \\
\text { concen- } \\
\text { tration } \\
(\mu \mathrm{mol} / \mathrm{l})\end{array}$ & N & \\
\hline $20-29$ & 0.129 & 20 & 0.075 & 21 & 0.003 \\
\hline $30-39$ & 0.174 & 20 & 0.094 & 19 & 0.001 \\
\hline $40-49$ & 0.191 & 20 & 0.145 & 22 & 0.104 \\
\hline $50-59$ & 0.182 & 21 & 0.130 & 21 & 0.070 \\
\hline $60-69$ & 0.178 & 20 & 0.156 & 17 & 0.411 \\
\hline $70-79$ & 0.151 & 8 & 0.137 & 7 & 0.770 \\
\hline $80-89$ & 0.310 & 1 & 0.155 & 2 & 0.361 \\
\hline $20-89$ & 0.169 & 110 & 0.117 & 109 & 0.001 \\
\hline
\end{tabular}

t-test, and multiple regression analysis was performed using the stepwise regression procedure with $P_{\text {in }}=0.05$ and $\mathrm{P}_{\text {out }}=0.10$ (a modified forward regression that permits reexamination, at every step, of the variables incorporated into the model in previous steps).

\section{Resuits}

Blood lead levels. The mean $\mathrm{B}-\mathrm{Pb}$ concentration of the population was $0.167 \mu \mathrm{mol} / \mathrm{l}$, with a mean of $0.191 \mu \mathrm{mol} / \mathrm{l}$ for the men and $0.143 \mu \mathrm{mol} / 1$ for the women (table 1).

Age and gender. The $\mathrm{B}-\mathrm{Pb}$ concentrations increased with age (table 1). They were generally higher for the men than for the women, and this difference was significant in the 2 youngest age decades (table 2 ). The B-Pb correlated positively with age among the women (table 1), whereas the correlation was weaker and not statistically significant for the men (table 1). Further analysis of the female participants revealed that the mean $\mathrm{B}-\mathrm{Pb}$ was significantly higher for women who had reached menopause than for women who had not (table 3).

Life-style exposures. Regular smokers had slightly elevated B-Pb levels, as compared with nonsmokers (table 3 ), and inhalation did not affect the B-Pb levels of the smokers $(P=0.475)$. People with a weekly alcohol consumption below 5 drinks had significantly lower B-Pb concentrations than those with higher alcohol intake (table 3). Furthermore, people who daily took vitamins or vitamins with minerals had a significantly lower $\mathrm{B}-\mathrm{Pb}$ level than people who never used this kind of supplementation (table 3 ).

Residence and traffic. There were no significant associations between $\mathrm{B}-\mathrm{Pb}$ and residence in urban versus rural areas. Furthermore, neither traffic intensity at home nor the time used daily for commuting affected the $\mathrm{B}-\mathrm{Pb}$ to any significant extent.

Occupational exposures. Sixteen persons indicating that they were exposed to metal dust or metal fumes had elevated $\mathrm{B}-\mathrm{Pb}$ concentrations as compared with unexposed workers, but the difference was not significant (table 3). The B-Pb concentrations of persons exposed to exhaust gases were higher than those of unexposed persons, and the difference was of borderline significance (table 3 ).

Multiple regression. As the participation rates were low for people over 70 years of age, this group was excluded from the model, as was also 1 person with a reported weekly alcohol consumption of 70 drinks. From the predictors that were significant in the bivariate analysis, the following 4 variables were accepted by the model: gender, age, weekly alcohol consumption, and daily use of vitamins or vitamins with minerals (table 4). Further analysis revealed no indication of collinearity between the variables. Smoking did not add signifi- 
cantly to the model $(\mathrm{P}>0.05)$. The 4 variables explained a total of $34 \%$ of the variation.

\section{Discussion}

With the use of an identical analytical method for blood samples from a random selection of the general population, a mean $\mathrm{B}-\mathrm{Pb}$ concentration of 0.24 (SD 0.13) $\mu \mathrm{mol} / \mathrm{l}$ was obtained in 1988-1989, whereas the current mean $\mathrm{B}-\mathrm{Pb}$ concentration was $0.17 \mu \mathrm{mol} / \mathrm{l}$. Thus the $\mathrm{B}-\mathrm{Pb}$ has decreased significantly during the 5-6 years between samplings. The reduced $\mathrm{B}-\mathrm{Pb}$ concentrations can primarily be attributed to reductions in the amount of lead used in gasoline. During the latest sampling period, about $90 \%$ of cars used unleaded gasoline, and no more than $0.15 \mathrm{~g} / \mathrm{l}$ was added to the leaded qualities. Thus the reduced $\mathrm{B}-\mathrm{Pb}$ concentration in the general population can be seen as the remarkable success of a preventive effort. Identical findings have been reported from other countries, including the United States, Canada, Italy, and Taiwan $(3-5,11)$.

Age and gender significantly affect B-Pb $(3,6,11,12)$. These observations are confirmed in the present study under low-level exposure circumstances, where the $\mathrm{B}-\mathrm{Pb}$ of the men was, on the average, about $0.05 \mu \mathrm{mol} / 1$ higher than that of the women and age seemed to be significantly correlated with the $\mathrm{B}-\mathrm{Pb}$ concentration. However, the correlation with age was only significant for the women. Thus B-Pb levels seem to increase only up to an age of about 50 years among men, whereas they tend to continue increasing in women also after 50 years of age. Some of the age-related increase may be due to accumulated lead from previous exposures originating from gasoline with high lead contents. The increased $\mathrm{B}-\mathrm{Pb}$ level in women over 50 years of age has previously been linked to menopause $(6,13)$, and the present study confirms the results of these previous studies as postmenopausal women had significantly higher B-Pb levels than premenopausal women. The increased B-Pb level in postmenopausal women may be of relevance, as mild cognitive deficits have been reported in older women with $\mathrm{B}-\mathrm{Pb}$ levels as low as $0.38 \mu \mathrm{mol} / 1$ (2). In our Danish population, about $4 \%$ of the women had B-Pb concentrations above $0.38 \mu \mathrm{mol} / \mathrm{l}$, as did $7 \%$ of the men. Although the number of participants with an increased $\mathrm{B}-\mathrm{Pb}$ was too low to reach a firm conclusion, the data indicate that a small proportion of the general population may still have an increased lead exposure, despite the fact that mean levels of $\mathrm{B}-\mathrm{Pb}$ have decreased to indeed very low levels.

Previously, lead levels could be related to well-known exposure sources from work or traffic exhaust. The present study demonstrates that differences related to residence, traffic, and work are of only marginal importance in relation to $\mathrm{B}-\mathrm{Pb}$. With decreasing occupational exposures and more homogeneous exposures from the general environment, it can be expected that life-style factors to a larger degree would affect $\mathrm{B}-\mathrm{Pb}$ in the population.
Table 3. Geometric mean blood lead (B-Pb) concentration in selected groups of the reference population.

\begin{tabular}{|c|c|c|c|}
\hline & $\mathrm{N}$ & $\begin{array}{c}\text { Geometric } \\
\text { mean } \mathrm{B}-\mathrm{Pb} \\
\text { concentration } \\
(\mu \mathrm{mol} / \mathrm{l})\end{array}$ & $\begin{array}{c}\text { Different from } \\
\text { previous } \\
\text { group }(P)\end{array}$ \\
\hline \multicolumn{4}{|l|}{ Alcohol intake } \\
\hline $\begin{array}{l}<5 \text { drinks per week } \\
>4 \text { drinks per week }\end{array}$ & $\begin{array}{r}87 \\
130\end{array}$ & $\begin{array}{l}0.099 \\
0.177\end{array}$ & $<0.001$ \\
\hline \multicolumn{4}{|c|}{$\begin{array}{l}\text { Daily supplement with vitamin } \\
\text { and minerals }\end{array}$} \\
\hline $\begin{array}{l}\text { Yes } \\
\text { No }\end{array}$ & $\begin{array}{r}38 \\
101\end{array}$ & $\begin{array}{l}0.114 \\
0.163\end{array}$ & 0.001 \\
\hline \multicolumn{4}{|l|}{ Smoking } \\
\hline $\begin{array}{l}\text { Regular smokers } \\
\text { Nonsmokers }\end{array}$ & $\begin{array}{r}82 \\
123\end{array}$ & $\begin{array}{l}0.154 \\
0.134\end{array}$ & 0.098 \\
\hline \multicolumn{4}{|l|}{$\begin{array}{l}\text { Exposure to metal dust } \\
\text { or fumes }\end{array}$} \\
\hline $\begin{array}{l}\text { Yes } \\
\text { No }\end{array}$ & $\begin{array}{r}16 \\
105\end{array}$ & $\begin{array}{l}0.184 \\
0.145\end{array}$ & 0.120 \\
\hline \multicolumn{4}{|c|}{ Exposure to exhaust gases } \\
\hline $\begin{array}{l}\text { Yes } \\
\text { No }\end{array}$ & $\begin{array}{r}22 \\
102\end{array}$ & $\begin{array}{l}0.187 \\
0.144\end{array}$ & 0.056 \\
\hline \multicolumn{4}{|l|}{ Women } \\
\hline $\begin{array}{l}\text { Premenopausal } \\
\text { Postmenopausal }\end{array}$ & $\begin{array}{l}54 \\
43\end{array}$ & $\begin{array}{l}0.095 \\
0.145\end{array}$ & $<0.001$ \\
\hline
\end{tabular}

Table 4. Multiple regression using a stepwise regression procedure and In(lead) as a dependent variable. The population was restricted to people below 70 years of age with a weekly alcohol consumption below 60 drinks.

\begin{tabular}{lccc}
\hline & $\begin{array}{c}\text { Regression } \\
\text { coefficienta }\end{array}$ & $\begin{array}{c}\text { Standard } \\
\text { error }\end{array}$ & P-value \\
\cline { 2 - 4 } & 0.308 & 0.091 & 0.0010 \\
Gender & 0.009 & 0.003 & 0.0058 \\
Age & & & \\
Vitamin and mineral & -0.163 & 0.050 & 0.0014 \\
supplementation & 0.016 & 0.004 & 0.0004 \\
Weekly alcohol consumption & & \\
\hline
\end{tabular}

a $R=0.602$, adjusted $r^{2}=0.342$

Smoking and alcohol consumption have been previously demonstrated to be positively associated with $\mathrm{B}-\mathrm{Pb}$ concentrations $(3,5,6)$. Our data confirm these observations. Thus people having more than 4 drinks per week had $80 \%$ higher $\mathrm{B}-\mathrm{Pb}$ concentrations on average than people with lower alcohol consumption, and regular smokers had higher average $\mathrm{B}-\mathrm{Pb}$ levels than nonsmokers. An interesting observation was the very strong negative association between the daily use of vitamins and minerals and the observed $\mathrm{B}-\mathrm{Pb}$. A partial correlation analysis and an analysis for collinearity did not show any relation to other life-style factors. Complex relations between $\mathrm{B}-\mathrm{Pb}$ concentrations and nutritional status have been previously described for human populations, for which individual factors such as zinc, iron, selenium, calcium, and vitamins $\mathrm{B}$ and $\mathrm{D}$ have been demonstrated to affect $\mathrm{B}-\mathrm{Pb}(1)$. However, at present, no definite biological explanation for the 
association can be suggested, and the association may be spurious or due to confounding.

The regression model for the population included only the variables gender, age, alcohol consumption, and daily intake of vitamins as significant independent variables. With a correlation coefficient of 0.6 , about $34 \%$ of the variance in $\mathrm{B}-\mathrm{Pb}$ was explained by these 4 variables. The limited number of predictors is probably due to the improved control of lead released to the environment. This preventive effort is also the reason for the reduced standard deviation and the small range of $\mathrm{B}-\mathrm{Pb}$ concentrations within our current population $[\mathrm{eg}$, in comparison with the population investigated in Denmark 8 years ago (6)].

\section{Acknowledgments}

The study was supported by the Danish Strategic Environmental Research Program financed by the Danish Government.

\section{References}

1. International Programme on Chemical Safety (IPCS). Inorganic lead. Geneva: World Health Organization, 1995. Environmental health criteria, no 165

2. Muldoon SB, Cauly JA, Kuller LH, Morrow L, Needleman HL, Scott $\mathrm{J}$, et al. Effects of blood lead levels on cognitive function of older women. Neuroepidemiology 1996;15:62-72.

3. Liou S-H, Wu T-N, Chiang H-C, Yang T, Yang G-Y, Wu Y-Q, et al. Three-year survey of blood lead levels in 8828 Taiwanese adults. Int Arch Occup Health 1996;68:80-7.
4. CDC. Update: blood lead levels - United States, 1991-1994. JAMA 1997;277:1031-2.

5. Bono R, Pignata C, Scursatone E, Rovere R, Natale P, Gilli G. Updating about reductions of air and blood lead concentrations in Turin, Italy, following reductions in the lead content of gasoline. Environ Res 1995;70:30-4.

6. Grandjean P, Nielsen GD, Jørgensen PJ, Hørder M. Reference intervals for trace elements in blood: significance of risk factors. Scand J Clin Lab Invest 1992;52:321-37.

7. Danmarks Statistik. Statistical yearbook 1994. Copenhagen: Danmarks Statistik, 1994:559.

8. Osler M. Smoking habits in Denmark from 1953 to 1991: a comparative analysis of results from three nationwide health surveys among adult Danes in 1953 - 1954, 1986-1987 and 1990-1991. Int J Epidemiol 1992;21:862-71.

9. Andersen HR, Nielsen JB, Nielsen F, Grandjean P. Antioxidative enzyme activities in human erythrocytes. Clin Chem 1997;43(4):562—8.

10. Nielsen F, Mikkelsen BB, Nielsen JB, Andersen HR, Grandjean P. Plasma malondialdehyde as biomarker for oxidative stress: reference interval and effect of life-style factors. Clin Chem 1997;43(7):1209-14.

11. Leung FY, Bradley C, Pellar TG. Reference intervals for blood lead and evaluation of zinc protoporphyrin as a screening test for lead toxicity. Clin Biochem 1993;26:491-6.

12. Brody D, Pirkle JL, Kramer RA, Flegal KM, Matte TD, Gunter EW, et al. Blood lead levels in the US population - phase 1 of the third national health and nutrition examination survey (NHANES III, 1988 to 1991). JAMA 1994;272:277-83.

13. Silbergeld EK, Schwartz J, Mahaffey KR. Lead and osteoporosis: mobilization of lead from bone in postmenopausal women. Environ Res 1989;47:79—94.

Received for publication: 18 November 1997 